ORNL/ER-412/R1

ENVIRONMENTAL RESTORATION PROGRAM

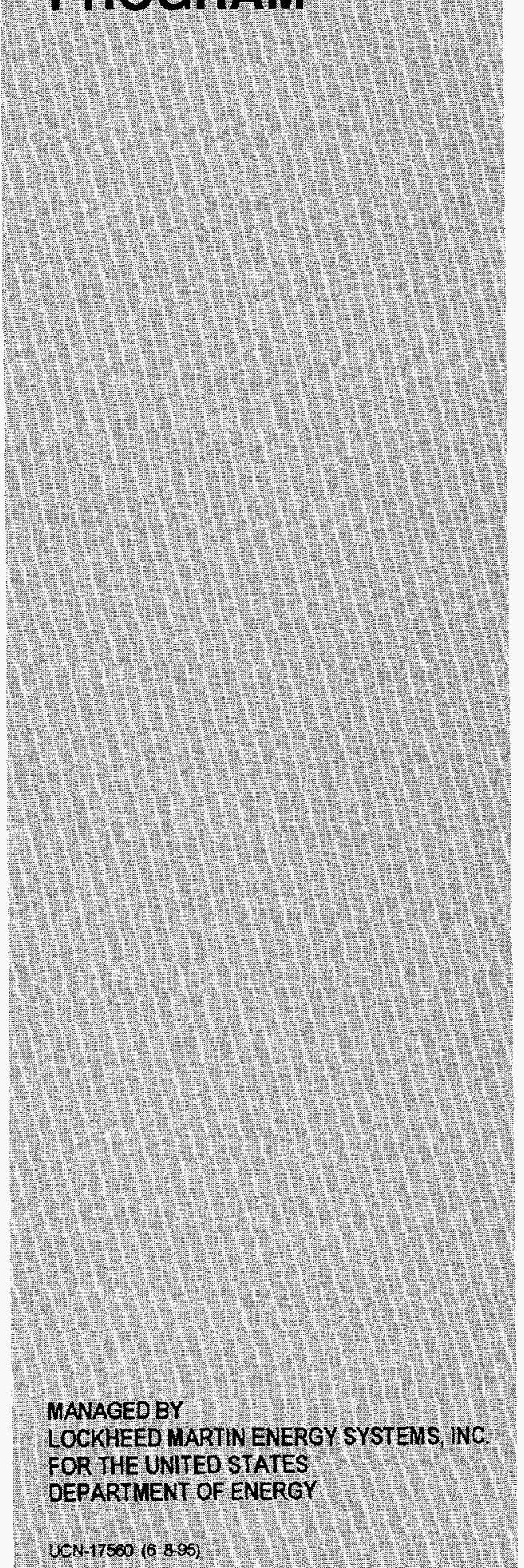

Sampling and Analysis Plan for the Gunite and Associated Tanks Interim Remedial Action, Wall Coring and Scraping at Oak Ridge National Laboratory, Oak Ridge, Tennessee

\section{RECEIVED}

FFR 131998

OSTI

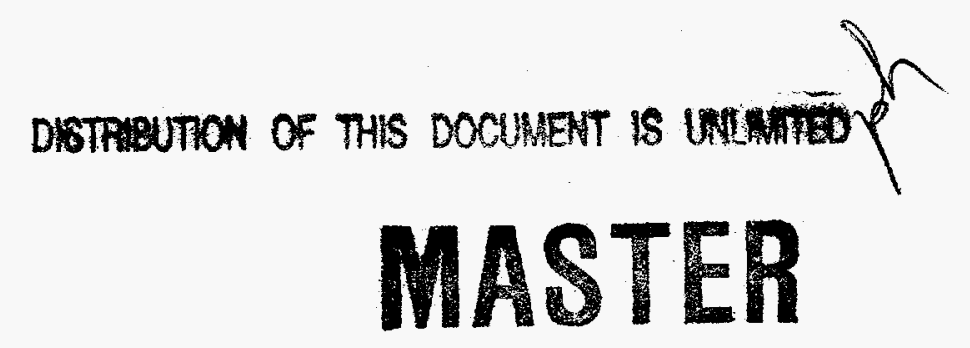

This document has been approved by the ORNL Technical Information Office for release to the public. Date: 02/09/97 


\section{DISCLAIMER}

This report was prepared as an account of work sponsored by an agency of the United States Government. Neither the United States Government nor any agency thereof, nor any of their employees, makes any warranty, express or implied, or assumes any legal liability or responsibility for the accuracy, completeness, or usefulness of any information, apparatus, product, or process disclosed, or represents that its use would not infringe privately owned rights. Reference herein to any specific commercial product, process, or service by trade name, trademark, manufacturer, or otherwise does not necessarily constitute or imply its endorsement, recommendation, or favoring by the United States Government or any agency thereof. The views and opinions of authors expressed herein do not necessarily state or reflect those of the United States Government or any agency thereof. 


\section{DISCLAIMER}

Portions of this document may be illegible electronic image products. Images are produced from the best available original document. 


\title{
Sampling and Analysis Plan for the Gunite and Associated Tanks Interim Remedial Action, Wall Coring and Scraping at Oak Ridge National Laboratory, Oak Ridge, Tennessee
}

Date Issued-February 1998

\author{
Prepared for the \\ U.S. Department of Energy \\ Office of Environmental Management \\ under budget and reporting code EW 20 \\ Environmental Management Activities at \\ OAK RIDGE NATIONAL LABORATORY \\ Oak Ridge, Tennessee 37831 \\ managed by \\ LOCKHEED MARTIN ENERGY SYSTEMS, INC. \\ for the \\ U.S. DEPARTMENT OF ENERGY \\ under contract DE-AC05-84OR21400
}


APPROVALS

Sampling and Analysis Plan for the Gunite and Associated Tanks Interim Remedial Action, Wall Coring and Scraping at Oak Ridge National Laboratory, Oak Ridge, Tennessee

(ORNL/ER-412/R1)

February 1998
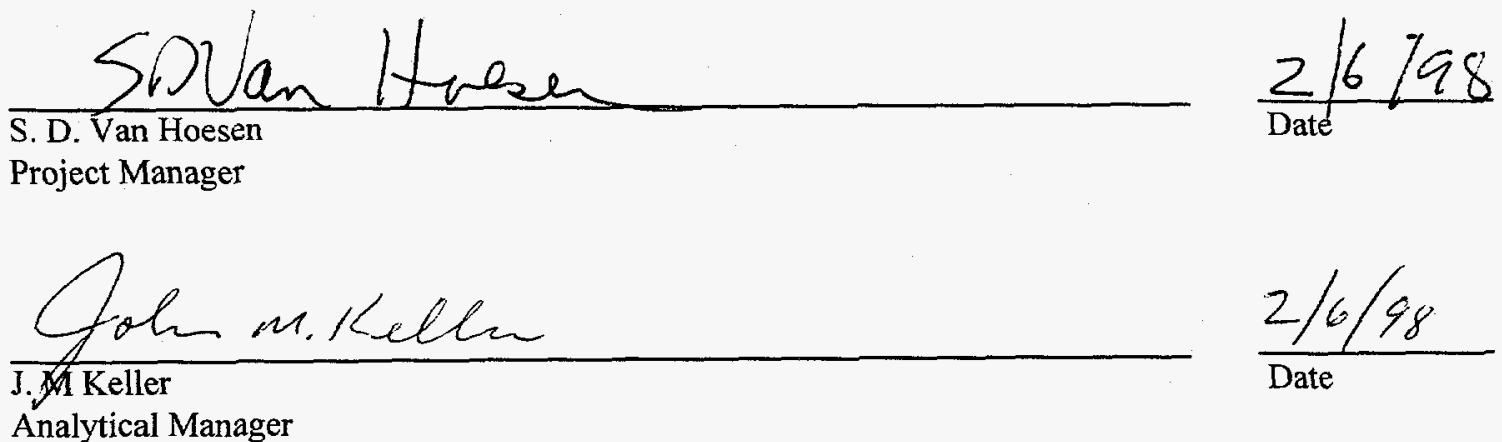

S.D. Van Hoesen Project Manager
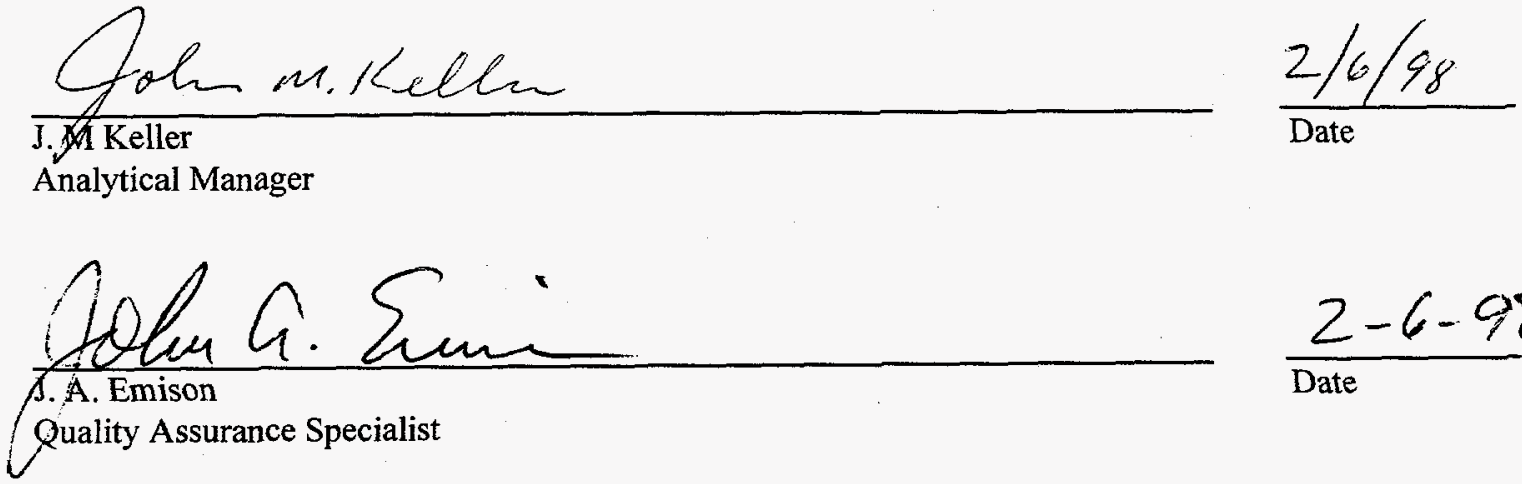

$\frac{2-6-98}{\text { Date }}$

B.A. Bunter

B. L. Burks

$\frac{2 / 6 / 88}{\text { Date }}$

Waste Removal Operations Manager 


\section{PREFACE}

This document, Sampling and Analysis Plan for the Gunite and Associated Tanks Interim Remedial Action, Wall Coring and Scraping at Oak Ridge National Laboratory, Oak Ridge, Tennessee (ORNL/ER-412/R1), was developed under Work Breakdown Structure number 1.4.12.6.1.01.41.12.04.03.06 (U.S. Department of Energy-Headquarters Activity Data Sheet OR3300W) for the Gunite and Associated Tanks (GAAT) Remediation Project. This document provides the GAAT Project with a guide for performing sampling and analysis of tank wall corings and scrapings. 
!

.

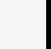
.

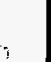




\section{CONTENTS}

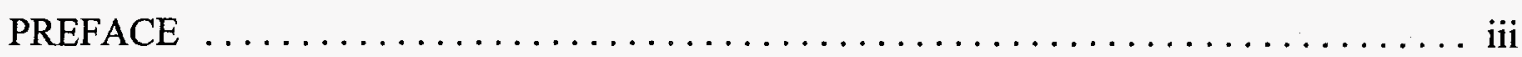

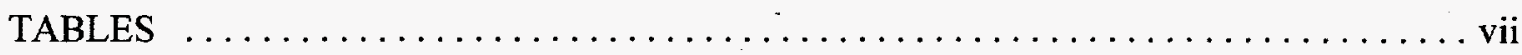

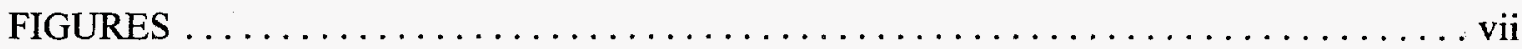

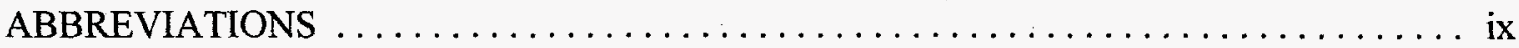

EXECUTIVE SUMMARY $\ldots \ldots \ldots \ldots \ldots \ldots \ldots \ldots \ldots \ldots \ldots \ldots \ldots \ldots \ldots \ldots \ldots$

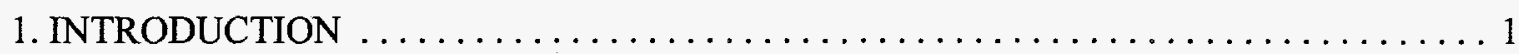

2. SAMPLING RATIONALE, PRIORITY, AND ANALYSIS $\ldots \ldots \ldots \ldots \ldots \ldots \ldots \ldots 2$

3. WALL SCRAPING AND CORING SAMPLING ACTIVITIES $\ldots \ldots \ldots \ldots \ldots \ldots \ldots 3$

4. ANALYSIS PROCEDURES FOR SAMPLES $\ldots \ldots \ldots \ldots \ldots \ldots \ldots \ldots \ldots \ldots$

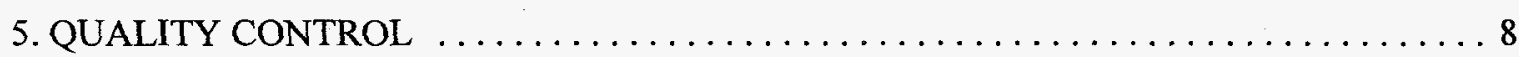

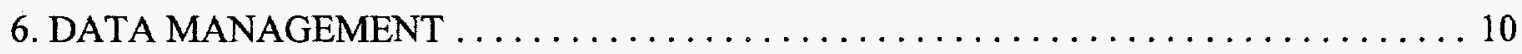




\section{TABLES}

1 Data quality objectives for GAAT sampling and analysis activities $\ldots \ldots \ldots \ldots \ldots \ldots 2$

2 Priority and rationale for GAAT sampling and analysis activities $\ldots \ldots \ldots \ldots \ldots \ldots \ldots 2$

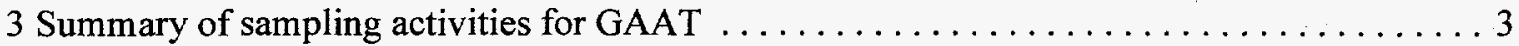

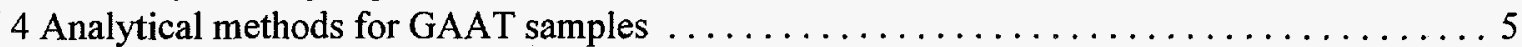

5 Analysis summary for GAAT samples $\ldots \ldots \ldots \ldots \ldots \ldots \ldots \ldots \ldots \ldots \ldots \ldots$

\section{FIGURES}

1 Overall analysis scheme for GAAT $\mathrm{W}-3$ wall scraping samples $\ldots \ldots \ldots \ldots \ldots \ldots \ldots 6$

2 Overall analysis scheme for GAAT wall core samples $\ldots \ldots \ldots \ldots \ldots \ldots \ldots \ldots \ldots$ 


\section{ABBREVIATIONS}

EPA

GAAT

ORNL

RMAL
U.S. Environmental Protection Agency

Gunite and Associated Tanks

Oak Ridge National Laboratory

Radioactive Materials Analytical Laboratory 


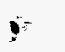




\section{EXECUTIVE SUMMARY}

This Sampling and Analysis Plan documents the procedures for collecting and analyzing wall core and wall scraping samples from the Gunite and Associated Tanks. These activities are being conducted to support the Comprehensive Environmental Response, Compensation, and Liability Act at the Gunite and Associated Tanks Interim Remedial Action at Oak Ridge National Laboratory in Oak Ridge, Tennessee. The sampling and analysis activities will be performed in concert with sludge retrieval and slucing of the tanks. Wall scraping and/or wall core samples will be collected from each quadrant in each tank by using a scraping sampler and/or a coring drill deployed by the Houdini robot vehicle. Each sample will be labeled, transported to the Radioactive Materials Analytical Laboratory, and analyzed for physical and radiological characteristics, including total activity, gross alpha, gross beta, radioactive strontium and cesium, and other alpha- and gamma-emitting radionuclides. The data quality objectives process, based on U.S. Environmental Protection Agency guidance (EPA QAG-4, September 1994), was applied to identify the objectives of this sampling and analysis. The results of the analysis will be used to (1) validate predictions of a strontium concrete diffusion model, (2) estimate the amount of radioactivity remaining in the tank shells, (3) provide information to correlate with measurements taken by the Gunite Tank Isotope Mapping Probe and the Characterization End Effector, and (4) estimate the performance of the wall cleaning system. This revision eliminates wall-scraping samples from all tanks, except Tank W-3. The Tank W-3 experience indicated that the wall scrapper does not collect sufficient material for analysis. 


\section{INTRODUCTION}

This Sampling and Analysis Plan documents the collection and analysis of wall core and/or wall scraping samples from the Gunite and Associated Tanks (GAAT). These activities are being conducted to support the Comprehensive Environmental Response, Compensation, and Liability Act for the GAAT Interim Remedial Action at Oak Ridge National Laboratory (ORNL) in Oak Ridge, Tennessee. The sampling and analysis activities will be conducted in concert with sludge retrieval and sluicing of the tanks. Each sample will be labeled, transported to the Radioactive Materials Analytical Laboratory (RMAL), and analyzed for physical and radiological characteristics. The data quality objectives process, based on U.S. Environmental Protection Agency (EPA) guidance (EPA QA/G-4, September 1994), was applied to identify the objectives of this sampling and analysis. The results of the analysis will be used to (1) confirm predictions of a strontium concrete diffusion model, (2) estimate the amount of radioactivity remaining in the tank shells, (3) provide information to correlate with measurements taken by the Gunite Tank Isotope Mapping Probe and Characterization End Effector, and (4) estimate the performance of the wall cleaning system.

As part of the sampling and analysis activities, a scraping device may be used to obtain samples of material adhering to the wall surface in Tank W-3. A drilling tool deployed by the Houdini robot vehicle will be used to obtain core samples of the gunite walls. Analysis of the samples will include the following:

- a record of visual observations (color, texture, etc.), including video recording and a digital color photograph;

- total activity by liquid scintillation;

- gross alpha and gross beta;

- total radioactive strontium; and

- other alpha- and gamma-emitting radionuclides, including ${ }^{137} \mathrm{Cs}$.

This plan documents those areas in which standard EPA procedures and protocols cannot be followed because of the nature of the tanks and their contents. Contamination and exposure control considerations (personnel exposure and tank configuration limitations) are the same as those discussed in the Radiation Work Permit, North Tank Farm Operations Plan, and Hazardous Waste Operations and Emergency Response plans; therefore, they are not addressed in this plan. Details of the sampling procedure for collecting and containerizing wall core samples are described in the Core Drill Operations Procedure (GAAT-TS/P-195). The Sample Chain of Custody Procedure (ESP-501 Rev. 2, 10/9/95) will be used by the field team for sample identification, chain of custody, sample tracking, data review, and sample security. A report of results will be issued after the sampling and analyses activities have been completed. 


\section{SAMPLING RATIONALE, PRIORITY, AND ANALYSIS}

The Data Quality Objectives pertinent to this plan are presented in Table 1; specific sampling parameters identified for each functional area are presented in Table 2.

Table 1. Data quality objectives for GAAT sampling and analysis activities

\begin{tabular}{lll}
\hline \multicolumn{1}{c}{ Question } & \multicolumn{1}{c}{ Data application } & \multicolumn{1}{c}{ Requirement } \\
\hline $\begin{array}{l}\text { 1. What is the wall surface } \\
\text { radioactive contamination before } \\
\text { the walls of Tank W-3 are } \\
\text { cleaned (sluiced/scarified)? }\end{array}$ & $\begin{array}{l}\text { Estimate radioactivity present on } \\
\text { tank wall surface (in material } \\
\text { absorbed onto the wall surface } \\
\text { that is readily removable) }\end{array}$ & $\begin{array}{l}\text { Collect wall surface scrapings } \\
\text { from identified undisturbed } \\
\text { areas and analyze for } \\
\text { radioactivity }\end{array}$ \\
$\begin{array}{l}\text { 2. What is the profile of } \\
\text { radioactive contamination in the } \\
\text { walls of Tank W-3 before it is } \\
\text { cleaned? }\end{array}$ & $\begin{array}{l}\text { Estimate radioactivity at } \\
\text { consistent depth intervals in tank } \\
\text { walls }\end{array}$ & $\begin{array}{l}\text { Collect wall core samples from } \\
\text { identified undisturbed areas } \\
\text { and analyze for radioactivity }\end{array}$ \\
$\begin{array}{l}\text { 3. What is the wall surface } \\
\text { radioactive contamination after } \\
\text { the walls of Tank W-3 are } \\
\text { cleaned? }\end{array}$ & $\begin{array}{l}\text { Estimate radioactivity present on } \\
\text { tank wall surface (in material } \\
\text { absorbed into the wall surface } \\
\text { that is readily removable) }\end{array}$ & $\begin{array}{l}\text { Collect wall surface scrapings } \\
\text { from identified cleaned areas } \\
\text { and analyze for radioactivity }\end{array}$ \\
$\begin{array}{l}\text { radioactive contamination in the } \\
\text { walls of the gunite tanks (W-3, }\end{array}$ & $\begin{array}{l}\text { Estimate radioactivity at } \\
\text { consistent depth intervals in tank } \\
\text { walls }\end{array}$ & $\begin{array}{l}\text { Collect wall core samples from } \\
\text { identified cleaned areas and } \\
\text { analyze for radioactivity }\end{array}$ \\
$\begin{array}{l}\text { W-4, W-5-6, W-7, W-8, W-9 }-9 \\
\text { and W-10) after they are cleaned? }\end{array}$ & & \\
\hline
\end{tabular}

Table 2. Priority and rationale for GAAT sampling and analysis activities

\begin{tabular}{cll}
\hline Item & $\begin{array}{c}\text { Priority and } \\
\text { functional area }\end{array}$ & \multicolumn{1}{c}{ Basis for sampling } \\
\hline 1 & Risk management & $\begin{array}{l}\text { Determine what the levels and distribution of radioactive strontium are on } \\
\text { the surface or within the first few centimeters of the interior wall of the tank } \\
\text { shell to compare with the prediction of the concrete diffusion model for } \\
\text { strontium (Risk Assessment Pathwoy/Transport Modeling for the Gunite and } \\
\text { Associated Tanks, Oak Ridge National Laboratory, Oak Ridge, Tennessee, } \\
\text { DOE/OR/02-1454\&D1, March 1996) } \\
\text { Estimate the amount of radioactivity in the tank shells after wall cleaning } \\
\text { (sluiced/scarified) to provide a basis for final tank shell disposition decisions } \\
\text { or further study }\end{array}$ \\
2 & $\begin{array}{l}\text { Compare the estimated total radioactivity in the tank shells before and after } \\
\text { wall cleaning to determine the effectiveness of the wall cleaning operation } \\
\text { in removing wall surface contamination }\end{array}$ \\
& $\begin{array}{l}\text { Remediation } \\
\text { device design and } \\
\text { operation } \\
\text { (Tank W-3 only) } \\
\text { Measurement } \\
\text { device design and } \\
\text { operation }\end{array}$ & $\begin{array}{l}\text { Determine the correlation between wall scraping/coring results and the data } \\
\text { provided by the Gunite Tank Isotope Mapping Probe and Characterization } \\
\text { End Effector measurements to assess the reliability of using the Gunite Tank } \\
\text { Isotope Mapping Probe or Characterization End Effector to measure wall } \\
\text { contamination }\end{array}$ \\
\hline
\end{tabular}




\section{WALL SCRAPING AND CORING SAMPLING ACTIVITIES}

Table 3 is a listing of the wall scraping and/or coring sampling activities to be conducted in the GAAT. The wall-scraping device will be used to collect four to eght scraping samples from Tank W-3 only. Wall core samples will be collected, through the use of a coring drill deployed by the Houdini robot vehicle, from each location where a wall scraping was collected in Tank W-3, and eight cores will be retrieved from the remaining GAAT tanks (W-4, W-5, W-6, W-7, W-8, W-9, W-10). The total number of samples collected will depend on the technical limitations of deploying the sampling equipment and collecting the samples.

Table 3. Summary of sampling activities for GAAT

\begin{tabular}{|c|c|}
\hline Activity & Tanks \\
\hline $\begin{array}{l}\text { Wall scrape } \\
\text { samples for } \\
\text { Tank W-3 only }\end{array}$ & $\begin{array}{l}\text { 1. Divide tank into quadrants. These same quadrants will be used for all wall scraping } \\
\text { and coring sampling } \\
\text { 2. Within each quadrant, identify undisturbed and cleaned (i.e., cleaned with } \\
\text { sluicer/scarifier) areas of the tank wall that are appropriate for sampling } \\
\text { 3. Collect a wall scraping sample from an identified undisturbed area within each } \\
\text { quadrant, for a total of four individual samples } \\
\text { 4. Collect a wall scraping sample from an identified cleaned area within each } \\
\text { quadrant, for a total of four individual samples } \\
\text { 5. Place each scraping blade with one adhered wall sample into an individual } \\
\text { container, label, and send container to RMAL }\end{array}$ \\
\hline $\begin{array}{l}\text { Wall core } \\
\text { samples for each } \\
\text { tanks } \\
(\mathrm{W}-3, \mathrm{~W}-4, \mathrm{~W}-5 \text {, } \\
\mathrm{W}-6, \mathrm{~W}-7, \mathrm{~W}-8 \text {, } \\
\text { W-9, and W-10) }\end{array}$ & $\begin{array}{l}\text { 1. Collect wall core samples, up to } 4 \text { in. in length each, using a } 0.75 \text {-in. inner diameter } \\
\text { coring bit, from an identified undisturbed area within each quadrant (as close as } \\
\text { possible to the locations in Step } 3 \text { for wall scrape samples), for a total of four } \\
\text { individual core samples from Tank W-3 only. } \\
\text { 2. Collect wall core samples, up to } 4 \text { in. in length each, using a } 0.75 \text {-in. inner diameter } \\
\text { coring bit, from an identified cleaned area within each quadrant, for a total of four } \\
\text { to eight individual core samples from each tank. } \\
\text { 3. For each core sample, remove coring bit from drilling device while retaining core } \\
\text { sample in coring bit or remove core sample from bit (as appropriate), place bit or } \\
\text { core sample (as appropriate) into container, label, and send container to RMAL (see } \\
\text { Core Drill Operations Procedure, GAAT-TS/P-195) }\end{array}$ \\
\hline
\end{tabular}

Before sampling and analysis begins, the tanks will be divided into quadrants. If feasible, samples will be collected from two locations (one in a cleaned area and one in an undisturbed area) within each of the quadrants. The scraping and core samples will be collected from areas located up to 5 to $6 \mathrm{ft}$ above the tank floor. The distance above the floor is limited by the maximum extension of the drilling tool deployed by the Houdini robot vehicle. The GAAT Project Manager will determine the exact locations of where the wall samples are taken based on review of the wall videos and other existing data. Video inspection will be performed to guide the sampling devices and to evaluate the structural integrity of the walls at the scraping and coring locations. The location of the sample retrieval will be noted in the field logbooks with a cross-reference to the sample identity record submitted to the RMAL. Any unusual observations will be noted in the shift supervisor's log.

If the wall scraping sample is to be collected from the same location or near enough to the location of a core sample such that the drilling operation has the potential to dislodge readily removable surface contamination, then that scraping sample will be collected before the wall core 
sample is collected. This is to ensure the removable material is captured by the scraper and not already dislodged from the wall by the drilling.

A 1-in. outer diameter coring bit with a 0.75 -in. inner diameter will be used to obtain 0.75 -in.-diam cores. Initial wall cores will be taken to a depth into the wall of up to $1.5 \mathrm{in}$. If the radioanalytical results on the cores show that radioactivity does not penetrate to the full depth of these cores, then cores taken subsequently will also be up to $1.5 \mathrm{in}$. in depth. If radioanalytical results of the initial $1.5 \mathrm{in}$. cores show radioactivity does penetrate to the full depth of the cores, then taking additional, deeper (e.g., up to 4 in. long) cores will be considered and the decision made by the GAAT Project Manager. In no instance will the tank walls be penetrated entirely through.

Initial core samples will be taken as one core per coring bit to compare with subsequent core samples taken as more than one core per coring bit. Examination of the core integrity and comparison of the effects of the two sampling methods on the core integrity will be used by the GAAT Project Manager to determine whether to sample later cores as one per bit or multiple cores per bit.

Each sample will be transported to the RMAL after it is retrieved and placed in an appropriate container. Each wall-scraping sample will be retained on the scraper blade for transfer to the laboratory. Each core sample may be retained within the coring bit for transfer to the laboratory, or the core sample may be removed from the bit before transfer to the laboratory, depending on how intact the core sample remains if removed from the bit before transport to the laboratory. If a core sample is retained in the coring bit for transfer to the laboratory, then the laboratory will remove the core sample from the bit, decontaminate the bit, and return it to the GAAT team for taking more samples.

At the RMAL, samples will be transferred to a high radiation-level hot cell if gamma radiation levels exceed $500 \mathrm{mrem} /$ hour; otherwise, samples will be transferred to a radiochemical hood. Sample transfers will be coordinated with Waste Management, as required.

\section{ANALYSIS PROCEDURES FOR SAMPLES}

The RMAL, Building 2026 at ORNL, will receive the samples for physical observation and radiochemical analysis. Analyses conducted will follow standard EPA SW-846 or ORNL analytical chemistry procedures (Table 4). Standard procedure "Sample Management in the Radioactive Materials Analytical Laboratory, Building 2026 - CASD-OP-RML-AD02, Rev 1 " will be followed (i.e., standard procedure for sample receipt, $\log$ in and identity, chain of custody, sample tracking, data review, and sample security). The radiation level of the incoming sample will determine whether the sample is handled and prepared in a hood or hot cell. The appropriate methods used will be described in the laboratory's report of results to the GAAT program. In all cases, any deviations from written procedures during the sampling or analysis will be documented. Samples will be retained according to the laboratory's standard operating procedure (CASD-OP-RML-AD02), with the exception that no sample will be disposed of without written approval by the GAAT Project Manager. 
Table 4. Analytical methods for GAAT samples

\begin{tabular}{ll}
\hline \multicolumn{1}{c}{ Methods } & \multicolumn{1}{c}{ Analysis } \\
\hline $\begin{array}{l}\text { Sample Management in the Radioactive Materials } \\
\text { Analytical Laboratory, Building 2026 }\end{array}$ & Sample and data management \\
(CASD-OP-RML-AD02, Rev 1) & \\
RMAL-ORNL Quality Assurance Project Plan QAPjP & Quality assurance plan for laboratory analysis \\
for the Characterization of Radioactive Waste & \\
(QAP-X-96-CASD/RML-001) & \\
Gross Alpha and Gross Beta Radioactivity in Drinking & Gross alpha and beta radioactivity sample \\
Water (CASD-AM-EPA-900.0) & preparation \\
$\begin{array}{l}\text { Gamma-emitting Radionuclides in Drinking Water } \\
\text { (CASD-AM-EPA-901.1) }\end{array}$ & $\begin{array}{l}\text { Gamma emitting radionuclides sample } \\
\text { preparation }\end{array}$ \\
$\begin{array}{l}\text { Operation of Packard MO 2500TR Liquid } \\
\text { Scintillation Counter }\end{array}$ & $\begin{array}{l}\text { 1. Total activity by liquid scintillation } \\
\text { (CASD-AM-RML-RA12) }\end{array}$ \\
$\begin{array}{l}\text { Operation and Calibration of the Tennelec LB4000 } \\
\text { (CASD-AM-RML-RA02) }\end{array}$ & radionuclides analysis \\
$\begin{array}{l}\text { Determination of }{ }^{89} \text { Sr }{ }^{90} \text { Sr in High Level Samples } \\
\text { Using Extraction Chromatography }\end{array}$ & Radioactive strontium sample preparation \\
(CASD-AM-RML-RA13) & \\
$\begin{array}{l}\text { Operation and Calibration of the Canberra, Nuclear } \\
\text { Data Genie - ESP Data Acquisition and Processing } \\
\text { (CASD-AM-RML-RA04) }\end{array}$ & Alpha and gamma spectroscopy data \\
\hline
\end{tabular}

Figures 1 and 2 show the anticipated analysis schemes to characterize the wall scraping and core samples, respectively. As soon as the samples are transported to the RMAL, this process will begin. The scraping sample submitted to the laboratory is assumed to be mixed with sludge that has adhered to the wall surface. All samples will be removed from the sampling transport container and transferred to a hot cell or radiochemical hood, as appropriate. Before any sample treatment, the samples will be photographed with a color digital camera and video camera, and a physical description of the sample (color and consistency) will be documented.

The scraping sample will be removed from the scraper blade by appropriate means, such as scraping or gently rinsing the sample off the blade with distilled, deionized water. If there is a sufficient amount of sample material on the scraper blade such that it is visible and can be weighed (e.g., not just a smear on the blade), the sample will be weighed. Otherwise, the sample will be leached from the blade without weighing. If there is more sample material than is necessary for the analyses, then the material will be well mixed and a "representative aliquot" will be collected, weighed, and dissolved into solution. After completion of the analyses, the remaining sample material will be archived for possible future characterization.

The intact core will be gently washed by dipping into distilled, deionized water to remove surface contamination that may be caused by drag-down of material along the core surface from drilling into the wall. Core samples will then be sliced with a jewelry saw at consistent intervals: 0.25 -in. intervals for the first 1 -in. of the core starting from the interior wall surface end. The number of slices for the remainder of the core will be determined on a case-by-case basis by the project manager. To document where along the core each slice is taken, the photograph of the intact core 


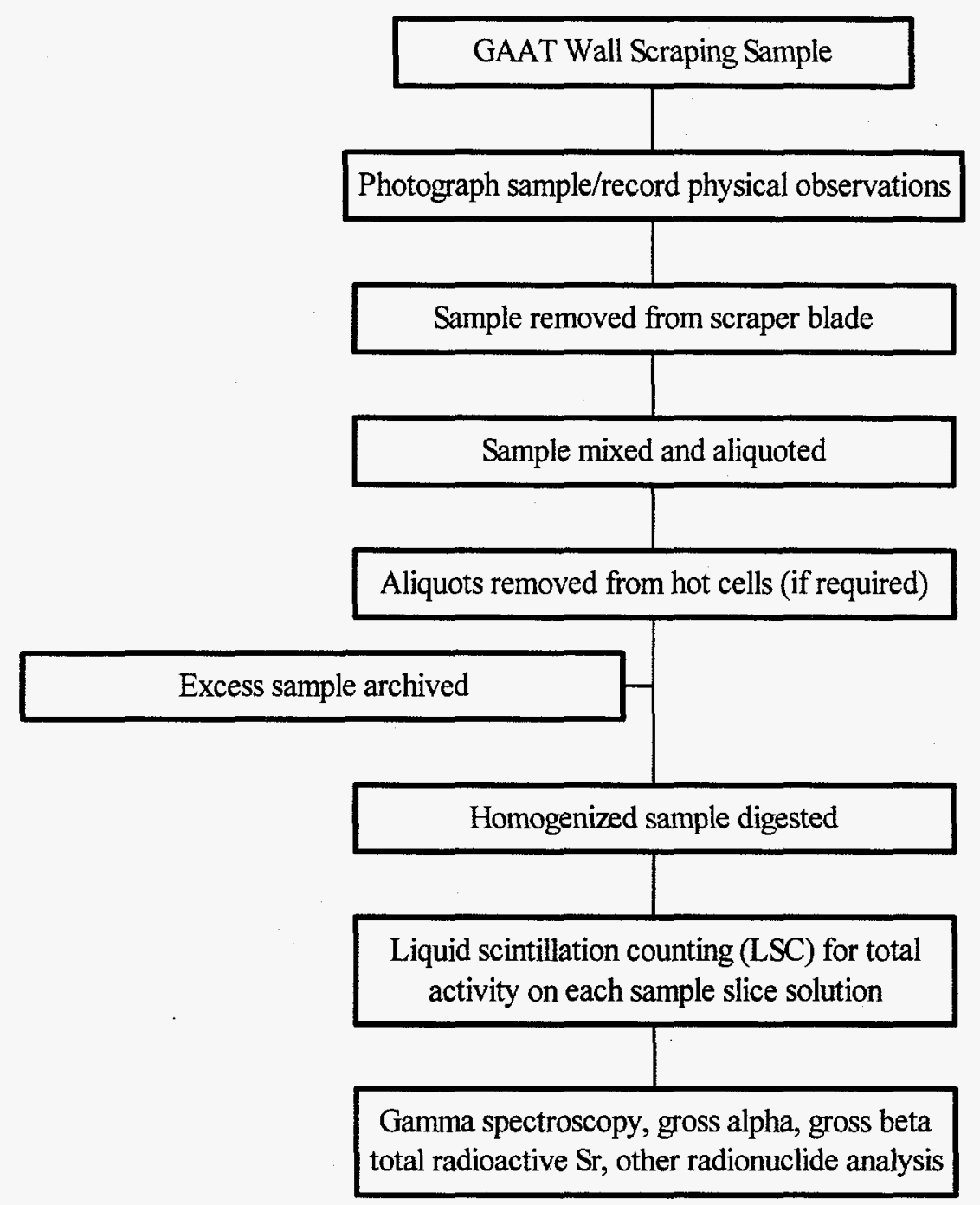

Fig. 1. Overall analysis scheme for GAAT W-3 wall scraping samples. 


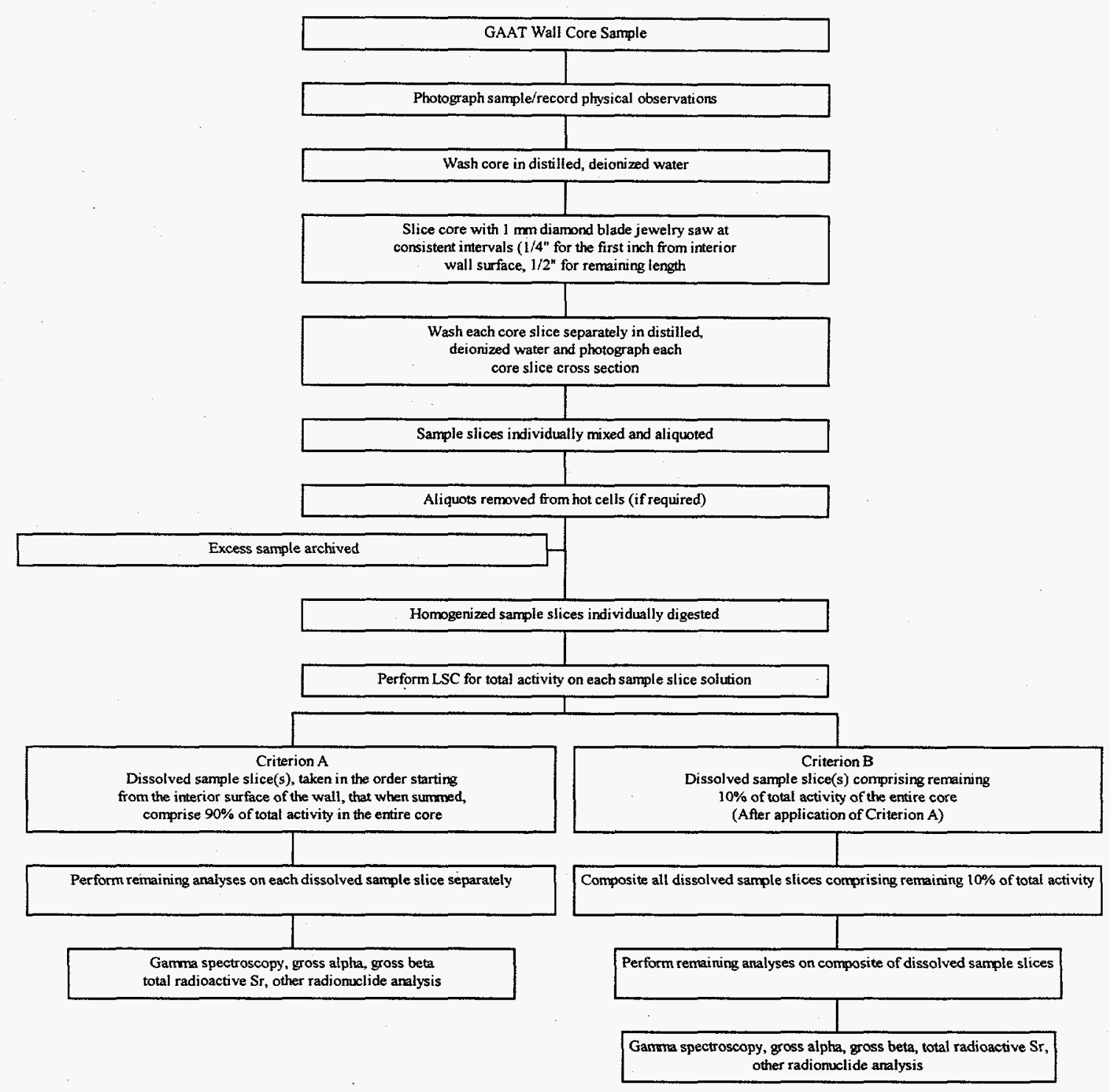

Fig. 2. Overall analysis scheme for GAAT wall core samples. 
will be marked, showing the location of each core slice cut, and each core slice will be identified and labeled to refer to its position in the original intact core. Each core slice will be gently rinsed in distilled, deionized water and digitally photographed, showing the cross sectional area. The slices will be dissolved into solution individually.

Liquid scintillation counting will be performed on each prepared wall scraping sample and each separate core slice sample. Before further radiochemical analyses of the prepared core slice samples, the RMAL will report the total activity measured by liquid scintillation in each slice to the GAAT Project Manager who will decide, in conjunction with RMAL staff, whether to composite the slices, based on the level of total activity. The slices, taken in the order starting from the interior surface of the wall, that account for the major percentage (approximately $90 \%$ ) of the total activity in the entire core will be retained as separate pieces. Those slices accounting for the remaining percentage of the total activity in the entire core will be composited.

Aliquots of the (individual or composited) digested sample will be taken for radionuclide analysis. Concentrations of radionuclides will be determined on an aliquot of sample sized according to the level of radioactivity. Samples will be analyzed for total activity, gross alpha/beta, radioactive $\mathrm{Sr},{ }^{137} \mathrm{Cs}$, and other radionuclides $\left({ }^{134} \mathrm{Cs},{ }^{60} \mathrm{Co},{ }^{152} \mathrm{Eu},{ }^{154} \mathrm{Eu},{ }^{155} \mathrm{Eu},{ }^{239} \mathrm{Pu} /{ }^{240} \mathrm{Pu},{ }^{238} \mathrm{Pu} /{ }^{241} \mathrm{Am},{ }^{241} \mathrm{Am}\right.$, and ${ }^{244} \mathrm{Cm}$ ) (Table 5).

Density measurements will be collected on each core sample by using the last internal slice of the core sample. The GAAT Project Manager may also request other miscellaneous measurements on specific core samples, and the results will be documented.

\section{QUALITY CONTROL}

All information generated during laboratory analysis will be filed in request folders, which will be retained by the laboratory. Copies will be made available for the tank project files. Documentation to be filed in the request folder for each analysis will include the following:

1. sample identity;

2. number and title of the standard procedure;

3. detailed, step-by-step description of any deviation from the standard procedures;

4. rationale for any procedural deviation;

5. results of any analysis, including results of percentage recovery of each spike and percentage difference of each set of duplicates; and

6. observations and sample description, including photos. 
Table 5. Analysis summary for GAAT samples

\begin{tabular}{|c|c|c|c|}
\hline Issues to be addressed & $\begin{array}{l}\text { Type of } \\
\text { sample }\end{array}$ & $\begin{array}{l}\text { Types of analysis to be performed } \\
\text { on each sample }\end{array}$ & Detection limit ${ }^{c}$ \\
\hline (1) Risk management & $\begin{array}{l}\text { Wall scraping } \\
\text { sample }^{a, b, e}\end{array}$ & $\begin{array}{l}\text { Visual observations (log description and digital } \\
\text { photo or video) }\end{array}$ & $\mathrm{N} / \mathrm{A}$ \\
\hline \multicolumn{4}{|l|}{ (2) Remediation } \\
\hline \multicolumn{4}{|l|}{$\begin{array}{l}\text { (3) Remediation device } \\
\text { design and operation }\end{array}$} \\
\hline \multicolumn{4}{|l|}{$\begin{array}{l}\text { (4) Measurement device } \\
\text { design and operation }\end{array}$} \\
\hline & & Liquid scintillation count (total activity) & $1 \mathrm{~Bq} / \mathrm{L}$ \\
\hline & & $\begin{array}{l}\text { Gamma spectroscopy for all significant gamma } \\
\text { emitters }\left({ }^{137} \mathrm{Cs} \text { in particular, }{ }^{134} \mathrm{Cs},{ }^{60} \mathrm{Co},{ }^{152} \mathrm{Eu},\right. \\
\left.{ }^{154} \mathrm{Eu},{ }^{155} \mathrm{Eu}\right)\end{array}$ & $0.374 \mathrm{~Bq} / \mathrm{L}^{d}$ \\
\hline & & Gross alpha by dry plate counting & $0.11 \mathrm{~Bq} / \mathrm{L}^{d}$ \\
\hline & & Gross beta using liquid scintillation counting & $0.15 / \mathrm{Bq} / \mathrm{L}^{d}$ \\
\hline & & Standard strontium separation & $0.074 \mathrm{~Bq} / \mathrm{L}^{d}$ \\
\hline & & $\begin{array}{l}\text { Alpha spectroscopy }\left({ }^{239} \mathrm{Pu} /{ }^{240} \mathrm{Pu},{ }^{238} \mathrm{Pu} /{ }^{241} \mathrm{Am},\right. \\
\left.{ }^{244} \mathrm{Cm},{ }^{241} \mathrm{Am}\right)\end{array}$ & $1 \mathrm{~Bq} / \mathrm{L}$ \\
\hline (1) Risk management & $\begin{array}{l}\text { Wall core } \\
\text { sample }^{a, b}\end{array}$ & $\begin{array}{l}\text { Visual observations (log description and digital } \\
\text { photo or video) }\end{array}$ & N/A \\
\hline \multicolumn{4}{|l|}{ (2) Remediation } \\
\hline \multicolumn{4}{|l|}{$\begin{array}{l}\text { (3) Remediation device } \\
\text { design and operation }\end{array}$} \\
\hline \multicolumn{4}{|l|}{$\begin{array}{l}\text { (4) Measurement device } \\
\text { design and operation }\end{array}$} \\
\hline & & Liquid scintillation count (total activity) & $1 \mathrm{~Bq} / \mathrm{L}$ \\
\hline & & $\begin{array}{l}\text { Gamma spectroscopy for all significant gamma } \\
\text { emitters }\left({ }^{137} \mathrm{Cs} \text { in particular, }{ }^{134} \mathrm{Cs},{ }^{60} \mathrm{Co},{ }^{152} \mathrm{Eu},\right. \\
\left.{ }^{154} \mathrm{Eu},{ }^{155} \mathrm{Eu}\right)\end{array}$ & $0.374 \mathrm{~Bq} / \mathrm{L}^{d}$ \\
\hline & & Gross alpha by dry plate counting & $0.11 \mathrm{~Bq} / \mathrm{L}^{d}$ \\
\hline & & Gross beta using liquid scintillation counting & $0.15 / \mathrm{Bq} / \mathrm{L}^{d}$ \\
\hline & & Standard strontium separation & $0.074 \mathrm{~Bq} / \mathrm{L}^{d}$ \\
\hline & & $\begin{array}{l}\text { Alpha spectroscopy }\left({ }^{239} \mathrm{Pu} /{ }^{240} \mathrm{Pu},{ }^{238} \mathrm{Pu} /{ }^{241} \mathrm{Am} \text {, }\right. \\
\end{array}$ & $1 \mathrm{~Bq} / \mathrm{L}$ \\
\hline
\end{tabular}

${ }^{a}$ Sample size may vary depending on sample tool effectiveness and collection method.

${ }^{b}$ Analysis protocols per RMAL ORNL Quality Assurance Project Plan for the Characterization of Radioactive Waste (QAP-X-96-CASD/RML-001).

'The detection limit for highly radioactive samples will vary and is dependent on such factors as dilutions, counting time, and background levels used during the measurements.

${ }^{d}$ These detection limits are based on the National Primary Interim Drinking Water Regulations.

${ }^{e}$ Scraping samples are taken from Tank W-3 only 
Review of data packages will be conducted using the laboratory's sample management standard operating procedures (CASD-OP-RML-AD02, Rev 1). This procedure includes security measures and the initiation and use of chain-of-custody forms.

Instrument logbooks will be maintained to record periodic balance and instrument maintenance. Daily instrument and balance checks will be recorded in these logbooks. Calibration data associated with specific analyses for this project will be filed in the analytical request folder.

Information pertaining to calibration standards, spiking standards, and reagents used will be retained in the logbooks. This information will include manufacturer, lot number, and expiration dates (if any) of stocks; dates prepared; and names of persons who prepared dilutions or dissolutions. At the completion of the project, all results and information about deviations from EPA SW-846 or ORNL analytical chemistry procedures will be compiled into a report. A discussion of the probable error for the analytical results will also be included in the report.

The quality control acceptance criteria for EPA methods from SW-846 may not always be applicable or practicable for highly radioactive samples. Modifying the procedures may be necessary for as low as reasonably achievable considerations. All deviations and dilutions, and the reason for the deviations and dilutions, will be documented and reported by RMAL. Error propagation will be documented and reported.

Ordinarily, trip blanks are submitted with each shipment of samples to the laboratory. However, because so few samples per tank will be collected over an extended period of time and submitted to the laboratory, no trip blanks will be submitted to the laboratory.

\section{DATA MANAGEMENT}

Once the data results have been collected at the laboratory, the data is verified and validated to the protocols in the RMAL ORNL Quality Assurance Project Plan for the Characterization of Radioactive Waste (QAP-X-96-CASD/RML-001). The results are collected in folders and placed into the laboratory files. A report of results is written and distributed to data users. Once the analytical data has been validated it will be formatted and released to the Oak Ridge Environmental Information System.

The results files in the laboratory; the field chain-of-custody forms; the shift supervisor log sheets for the days the sampling occurred; and the associated sampling plans, work plans, and associated documentation are collected into notebooks for submittal into the GAAT project files. Each sample is tracked on a spreadsheet and the activities that were requested are checked against the result report to ensure all requested data have been collected. If there are problems, then the problem area is flagged, a solution is sought for the problem area, and the problem is remedied. After all files have been collected and the result report has been added to the notebooks, the sampling results notebooks are added to the GAAT project files. Once the analytical data has been validated, it will be formatted and released to the Oak Ridge Environmental Information System. 


\title{
DISTRIBUTION
}

\author{
1. P. T. Owen \\ 2. L. B. Raulston \\ 3. S. D. Van Hoesen \\ 4. C. O. Wiles \\ 5. Central Research Library \\ 6. File-EMEF DMC-RC
}

